\title{
Assessing the vulnerability of farmers, fishermen and herdsmen to climate change: a case study from Nigeria
}

\section{Idris Nasiru Medugu and M. Rafee Majid*}

Center for Innovative Planning and Development, Department of Urban and Regional Planning,

Universiti Teknologi Malaysia,

81310 Johor Bahru, Johor, Malaysia

E-mail: medugu@gmail.com

E-mail: rafee@utm.my

*Corresponding author

\section{Walter Leal Filho}

Faculty of Life Sciences,

Hamburg University of Applied Sciences,

Hamburg, Lohbruegger Kirchstraße 65, Sector S4, Germany

E-mail: walter.leal@haw-hamburg.de

\begin{abstract}
This paper describes a study on the vulnerability of farmers and fishermen to climate change and the conflict arises between farmers and herdsmen, in Nigeria. A random sampling survey was carried out in some selected rural communities where 200 farmers and fishermen were interviewed and discussions with community focus groups to ascertain the level of their understanding of climate change issues. The study observed that the majority of the farmers had a good understanding of the changes in the climate through their personal observation, intervention of some research institutes and discussion in various cooperative society meetings. However, climate change has greatly impacted crop production with more than $50 \%$ reduction in produce, but not very much change has occurred to fish production. This study further noted that the respondents are faced with increased variations in rainfall and temperature patterns and are yet to have good adaptive measures to the current and expected changes. This paper has recommended the use of agroforestry programme, or tree cropping system, which is a potential strategy to help farmers reduce their vulnerability to climate-related hazards and sustainable fish farming to minimising the vulnerability of fishermen to climate disasters.
\end{abstract}

Keywords: adaptation; Agroforestry; climate change; farmers; fishermen; herdsmen; Nigeria; vulnerability; global warming.

Reference to this paper should be made as follows: Medugu, I.N., Majid, M.R. and Leal Filho, W. (2014) 'Assessing the vulnerability of farmers, fishermen and herdsmen to climate change: a case study from Nigeria', Int. J. Global Warming, Vol. 6, No. 1, pp.1-14. 
Biographical notes: Idris Nasiru Medugu is a researcher of Universiti Teknologi Malaysia under the Postdoctoral Fellowship Scheme for the project: 'Community-level management of the effects of land use/land cover changes on the magnitude and frequency of flooding'. His research interest includes desertification management, drought mitigation, sustainable management of agricultural land, disaster management, climate change assessments and environmental planning.

M. Rafee Majid is the Head of Department (Postgraduate Studies and Research) at the Faculty of Built Environment, Universiti Teknologi Malaysia and he is also an Associate Professor in the Department of Urban and Regional Planning in the same faculty. His research interest includes environmental planning, spatial statistics, watershed planning and application of GIS in environmental planning and management.

Walter Leal Filho is a Senior Professor and works at the Centre for International Business and Sustainability (CIBS) at London Metropolitan University Business School; he also heads the research and transfer centre 'Applications of Life Sciences' at the Hamburg University of Applied Sciences in Germany.

\section{Introduction}

There is increasing evidence that climate change is occurring. Leal Filho (2009) observed that, last ten years have shown a particularly intense increase in the degree of emphasis to climate issues as a whole and the level of attention pay to climate change in particular. According to the Intergovernmental Panel on Climate Change (IPCC, 2007a) fourth assessment report that, there is "very high confidence that the global average net effect of human activities since 1750 has been one of warming". Climate change has developed into an issue of widespread and major concern where efforts for mitigation and adaptation to changing conditions have been strongly recommended by the IPCC (2007b) and put high on the political agendas of major governmental bodies, e.g., the EU (Grundman, 2007). Recent evidence and predictions indicate that climate changes are accelerating and will lead to wide-ranging shifts in climate variables (Al-Amin and Filho, 2011). There will be changes in the mean and variance of rainfall and temperature, extreme weather events, variation in food and agriculture production and prices, water availability and access, nutrition and health status. The most adverse impacts are predicted in the developing world because of geographic exposure, reliance on climate sensitive sectors, low incomes, and weak adaptive capacity. Socio-economic impacts, though generally not well understood, are likely to be profound and will impact humans through a variety of direct and indirect pathways (IPCC, 2007b; Cline, 2007; Stern, 2006).

With the understanding that local people, most especially those in developing countries are to be worst hit by the changes in climate, it becomes imperative to investigate their perception of the phenomenon and examine their adaptation strategies to the perceived changes.

From the British Columbian coast (Turner, 2009) to the Kalahari Desert to the English countryside (Lawrence, 2009) and to the Himalayan Mountains (Salick et al., 
2006) local people are experiencing local changes in climatic conditions. Indigenous peoples are not only keen observers of climate changes but also actively trying to adapt to the changing conditions (Salick and Byg, 2007; Macchi et al., 2008). In general, there appears to be a hierarchy of responses, whereby as conditions worsen, additional physical and biological responses are added and social and political relations become more important for providing resources for basic survival (Berkes et al., 2000).

Furthermore, documenting local perceptions of climate change is also important from a policy point of view, since local perceptions reflect local concerns (Danielsen et al., 2005) and focus on the actual impacts of climate change on people's lives (Laidler, 2006), which are dependent on local factors that cannot be estimated through models (van Aalst et al., 2008). In addition, local knowledge and perceptions influence people's decisions both in deciding whether or not to act (Alessa et al., 2008) and what measures are taken over both short and long-terms (Berkes and Jolly, 2001). Therefore, local observations and perceptions should be taken into account in efforts to understand climate change, its impacts, adaptation to it, and mitigation of it. Unfortunately, until recently, local knowledge of climate change and its impacts has largely been ignored by most climate change studies [with a few exceptions such as Vedwan and Rhodes (2001), Krupnik and Jolly (2002), and Couzin (2007)].

Nigeria is one of the countries expected to be most affected by the impacts of climate change through sea level rise along her coastline, intensified desertification, erosion and flooding disasters and general land degradation (Medugu et al., 2010). According to Medugu (2009), Nigeria will lose close to $\$ 9$ billion as a result of the catastrophe while, at least, $80 \%$ cent of the inhabitants of the Niger Delta region of the country will be displaced due to the low level of the oil-rich region (below sea level). Nigeria is highly vulnerable to the impacts of climate change and the country's fragile economy makes the local ability to respond difficult. Nigeria has a variety of ecosystems, from mangroves and rainforests on the Atlantic coast in the south to the savannah in the north bordering the Sahara. Whether dry or wet, those ecosystems are being battered by global warming. While excessive flooding during the past decade has hurt farming in coastal communities, desertification is ravaging the Sahel. Traditionally, desertification in the Sahel has been blamed on overgrazing practices of the local population, but it has been discovered that the real problem is climate change (Medugu et al., 2009). Rainfall in the Sahel has been declining steadily since the 1960s and this has resulted in the loss of farmlands and conflicts between farmers and herdsmen over ever decreasing grass land. Many different communities, especially fish farmers, crop farmers and herdsmen, are now confronted with difficulties arising from climatic changes. Peoples' livelihoods are being harmed, and people who are already poor are becoming even more impoverished. Climate refugees are the result, as the changes make some land unlivable and affect water supplies.

The majority of the country's rural populace is employed in the agricultural sector which contributes about 5\% to the Nigerian gross domestic product (GDP) (Zaku, 2009). The dominant role of agriculture in sustaining rural livelihoods makes it obvious that even minor climate deteriorations can cause devastating socio-economic consequences. This makes it imperative to assess the level of the country's vulnerability and readiness for adaptability to the climate change phenomena

However, it will be nearly impossible for preparations to be made towards adapting to these changes if this phenomenon is not properly understood, especially from the angle of 
the most affected parties. Therefore, the purpose of this paper is to study the perception of farmers and fishermen on climate change and its effect on crop and fish production as well as their sustainability measures on a local scale.

\section{The study area}

Nigeria is located in West Africa and shares land borders with the Republic of Benin in the west, Chad and Cameroon in the east, and Niger in the north. Its coast lies on the Gulf of Guinea, a part of the Atlantic Ocean (Figure 1). It has a total land area of $923,773 \mathrm{~km}^{2}$ and 140 million populations and its people consist of over 200 ethnic groups, speaking about 395 languages and dialects (Medugu et al., 2008).

Figure 1 Map of Africa showing Nigeria (see online version for colours)

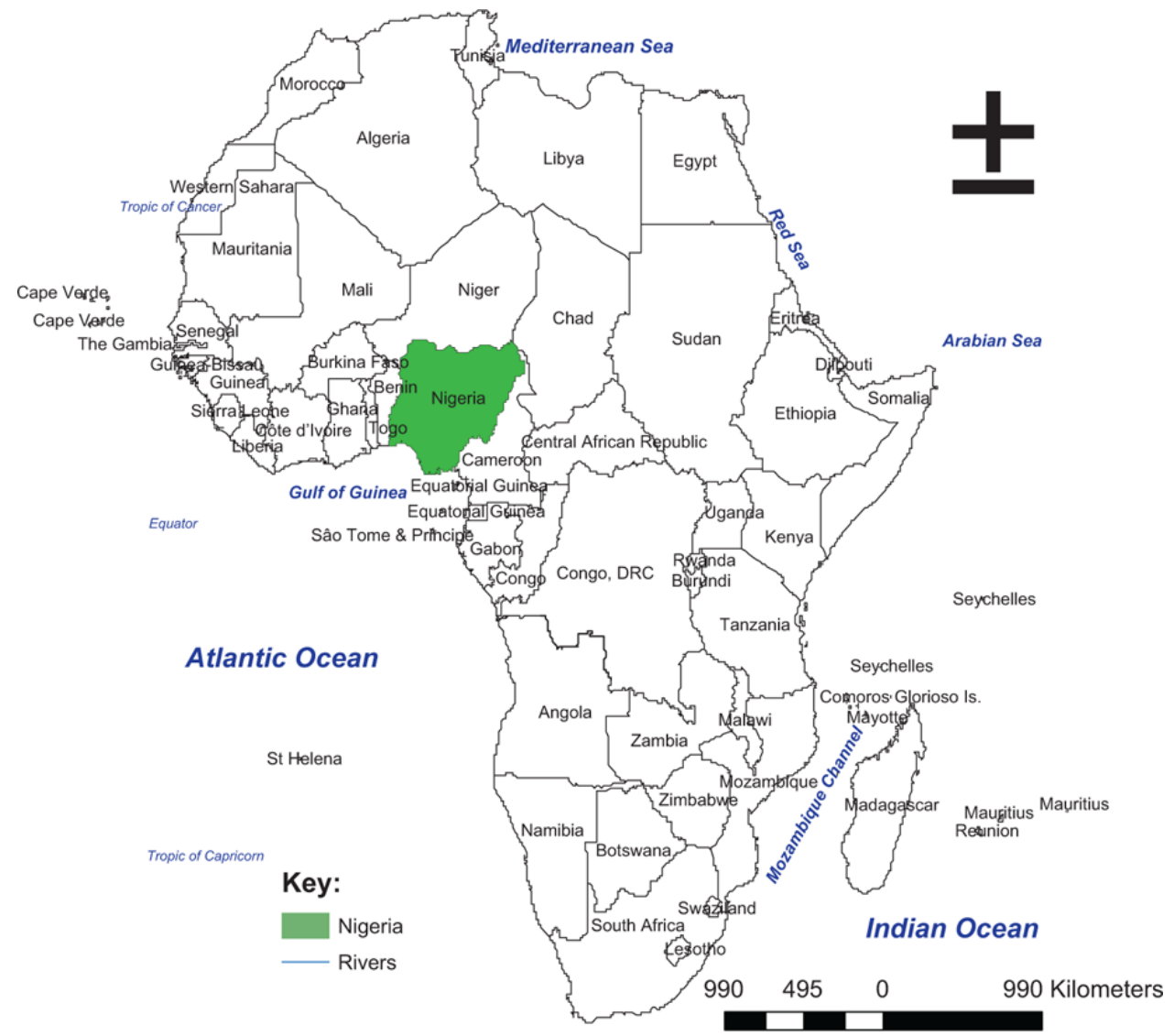

Source: Nelson (2010)

\subsection{Impact of climate change on Nigeria}

In Nigeria, agriculture is the main source of food, and a major source of industrial raw material. It employs close to $70 \%$ of Nigeria's population (Medugu et al., 2009). 
Agricultural practice in the country is predominantly rain-fed and therefore particularly vulnerable to the impacts of climate change. Nigeria's vulnerability will be in two ways; first, the resulting impacts of climate change and second, the impact of response measures.

A study projection by Awosika et al. (1992) in Nasiru (2009) suggests that Nigeria will experience massive 'environmental refugee' migration. For a $1 \mathrm{~m}$ rise in sea level, more than 3 million people are at risk, the estimated number of people that would be displaced ranges from 740,000 for a $0.2 \mathrm{~m}$ rise to 3.7 million for a $1 \mathrm{~m}$ rise and 10 million for a $2 \mathrm{~m}$ rise. Another study by Adesina and Adejuwom (1994) shows that biological productivity in Nigeria will decrease in the event of global warming; with an additional consequence of severe fuel-wood shortages. Nigeria's low-lying lagoonal coasts stand threatened by sea-level rise, particularly because most of its major and rapidly expanding cities are on the coast. In Africa and Nigeria, in particular, climate change impact poses great danger of desertification, damage to infrastructure, sea level rise, flooding and water salinity with serious implications to the well-being of the people. These impacts could manifest in food security challenges, damage to infrastructure and social dislocation. Additional impact is threat to health as rising temperature could bring about diseases like cerebral-spinal meningitis (CSM), malaria and other related illnesses.

Currently, 11 states in the northern part of the country are facing serious environmental degradation due to increasing desertification fuelled by climate change. The states are Adamawa, Borno, Bauchi, Gombe, Katsina, Jigawa, Kano, Kebbi, Sokoto, Yobe and Zamfara (Oluyole, 2012). There is a growing concern about the menace of desertification in Nigeria as some reports indicated that the country had lost about $23 \%$ of its arable land to desertification thereby affecting its food security. Besides, unpredictable rain patterns among other factors have virtually turned the south eastern parts of the country into huge gully erosion sites. A report of an NGO 'Building Nigeria's response to climate change' said that the impact of climate change could be serious and devastating. This is because some stable ecosystems in Nigeria such as the Sahel Savanna may become vulnerable, as global warming tends to reinforce existing patterns of water scarcity, while increasing the risks of drought in Nigeria and other West African countries.

Persistent droughts and flooding, off season rains and dry spells have sent growing seasons out of orbit. Alarm bells are ringing with lakes drying up and a reduction in river flow in the arid and semi arid region. The result is fewer water supplies for use in agriculture, hydro power generation and other uses. Droughts are getting worse and climate uncertainty is growing.

Climate change is an unprecedented threat to food security. Arid and semi-arid areas in northern Nigeria are becoming drier, while the southern part of the country are getting wetter. The impact of the change will be difficult to handle and it will be potentially very long lasting. Currently, there is an increasing incidence of disease, declining agricultural productivity, and a rising number of heat waves (Stringer et al., 2009). Declining rainfall in already desert-prone areas in northern Nigeria is causing increasing desertification and people in the coastal areas who used to depend on fishing have seen their livelihoods destroyed by the rising waters. 


\section{Method of study}

A study of vulnerability assessment by Marta and Alexandre (2012) stated that different conceptual perspectives and analytical approaches can be pursued in the analysis of climate change vulnerability which include top-down and bottom-up approaches which frame and assess vulnerability in different ways using different methods and tools. In line with the above statement, this study employed the use of quantitative and qualitative means of data gathering techniques as well as physical observations in order to study the vulnerability of climate change to farmers', fishermen and herdsmen in Nigeria. The approach adopted was based on some aspects of indicator-based approach for vulnerability assessment by Gallopin in 1997. Study by Chaliha et al. (2012) on climate variability and farmers' vulnerability refers to the term 'vulnerability' as commonly characterised as a function of three defining factors - exposure, sensitivity and adaptive capacity, which the study further reiterated basically concerns as coupled with human and environmental system. Therefore, these defining factors must be integrated into the vulnerability assessment irrespective of the differences that may exist in the levels or intensities of the three components (IPCC, 2001). And it also requires a framework for selecting indicator criteria that characterise the vulnerability of the coupled human-environment system. Indicators are commonly used to monitor trends on regional and national scales and, should not be confounded with a method that seeks to inform stakeholders of a place-base specific reaction in response to climate change impacts (IFPRI, 2008). Therefore, it is important to explain existing local knowledge bases for any existing adaptation strategies within a society/community as part of the assessment of adaptive capacity and stakeholder interests play important roles in vulnerability assessment.

Field work was carried out and 200 semi-structured questionnaires were administered to fishermen and farmers and discussion with five community focus groups (Table 1). Questionnaires were not administered to herdsmen because in Nigeria, herdsmen are nomadic therefore they were not stationed. Thus, the study examines the possible conflict that might arise between farmers and the herdsmen during the migration/movement of the herdsmen within the farmer's farmland as there were no grazing routes and reserves for them to adhere.

Table 1 No. of respondents/groups interviewed

\begin{tabular}{lc}
\hline Types of respondents & No. of respondents/groups \\
\hline Farmers & 100 \\
Fishermen & 100 \\
Community focus groups & 5 \\
\hline
\end{tabular}

The following research questions were integrated in the administration of the questionnaire to the respondents and the discussion with the community focus group:

1 What climatic changes have they experienced in the areas under cultivation?

2 To what extent are the fishermen and farmers aware of the variations taking place in climatic patterns?

3 How have the perceived changes affected the production of fish and crop produce? 
4 What measures are being taken by these fishermen and farmers to adapt to the impact of climate change?

\section{Results and discussion}

The results of this study are presented in Table $2.97 \%$ of the crop farmers stated that there have been changes in the climatic conditions while only $83 \%$ of the fish farmers interviewed noted the changes in the prevailing weather conditions. Majority of the crop farmers affirmed to have come about their knowledge of climate change through research institutes. Quite a number of respondents' also stated to know this through personal observation and through their various cooperative societies. The fish farmers on the other hand confirmed to have their cooperative societies as the source of their information on trends in climatic patterns. This indicates that knowledge about changing climatic conditions is well circulated among the various groups of farmers.

Table 2 Responses from Farmers and Fishermen during the administration of questionnaire

\begin{tabular}{|c|c|c|c|c|}
\hline \multirow{2}{*}{ Questions } & \multicolumn{2}{|c|}{ Farmers } & \multicolumn{2}{|c|}{ Fishermen } \\
\hline & Yes & No & Yes & No \\
\hline $\begin{array}{l}\text { Are you aware that there is been changes in climate in recent } \\
\text { times? }\end{array}$ & 97 & 3 & 83 & 17 \\
\hline For how long have you been aware of the changes in climate? & 79 & 21 & 64 & 36 \\
\hline $\begin{array}{l}\text { What factors come to your mind when climate change is been } \\
\text { talked about? }\end{array}$ & 81 & 19 & 55 & 45 \\
\hline Has climate change had any impact on your crop production? & 90 & 10 & - & - \\
\hline Has climate change had any impact on your fishing activities? & - & - & 88 & 22 \\
\hline Has there been an increment in crop production? & 35 & 65 & - & - \\
\hline Has there been an increment in volume of fishes available? & - & - & 74 & 36 \\
\hline $\begin{array}{l}\text { Does climate change determine the type of crops you cultivate } \\
\text { now? }\end{array}$ & 49 & 51 & - & - \\
\hline Does climate change determine the times you go fishing now? & - & - & 50 & 50 \\
\hline
\end{tabular}

Furthermore, the majority of crop farmers, with a 51\% majority acknowledged to have been noticing the changes for up to 15 years, while $28 \%$ only noticed this within the last five years. This however could be attributable to their years of experience in crop farming as the majority of the crop farmers had been cultivating crops for more than 15 years and so have had ample opportunity to observe the trends in climate and acquire relevant information that is required to have their crops thrive. However, it is also worth of note that those who started cultivation within the last five years have also observed changes in climatic trends. This is an indication to the tremendous amount of changes that have occurred within a short period of time, revealing therefore, that climate change is on the increase. While $64 \%$ of fishermen have acknowledged that, they have been noticing changes during the raining season especially rise in rivers and streams waters and also drying up of some ponds and streams during the dry season while $36 \%$ feels is just a normal routine in climate. 
$44 \%$, majorities of the farmers attributed their understanding of changes in climate to changes in rainfall and temperature patterns. It is quite understandable that this will be the most noticeable attributes they observe since these are the factors that most directly affect the production of crops. Over $80 \%$ of the crop farmers acknowledge that they have been experiencing increased temperatures in recent times while only $55 \%$ of fishermen attributed their changes as a result of temperature and rainfall.

It was revealed through discussion with the crop farmers that there has been more than $50 \%$ reduction in their crop production. Fish farmers on the other hand were indifferent as to the effect that climate has had on the volume of production of fish. They however, noted that climate influences their farming seasons. This study revealed that the people had noticed a variety of changes in climatic conditions especially in rainfall patterns. It also revealed that the respondents had heard of the term climate change but did not however realise that it was a global phenomenon and thought it a local occurrence. It was further revealed that the media had very little to do with the dissemination of information as touching climate change matters. Majority of the respondents had access to various means of mass media and therefore, the media need to play a more active role in propagating climate change matters.

Respondents' reported both negative and positive impacts of climate changes on their lives. However, the majority of the reported impacts were negative, chief among which is reduction in the crop and fish production. There has been a tremendous reduction in harvest output but not much change in the fish production. This has led to changes in the standard of living of most of the people because they are dependent on agriculture as their means of livelihood.

The respondents observed of excessively oppressive heat during the dry season. This leads to increased occurrence of pests and diseases which damage their crops and harvests and as well affects the lives of the locals. One major observation was the very low involvement of government authorities in contribution to the knowledge of the people as touching climate change phenomenon and therefore, no clear cut policies or plans that touch the lives of these locals were in place as at the time this study was carried out.

\subsection{Climate change vulnerability to farmers in Nigeria}

Nigerian farmers are exposed to both gradual climate change (e.g., temperature and precipitation) and extreme climate change (e.g., drought and flood). Exposure affects sensitivity, which means that exposure to higher frequencies and intensities of climate risk highly affects outcome (e.g., yield, income, health). Exposure is also linked to adaptive capacity. For instance, higher adaptive capacity reduces the potential damage from higher exposure (i.e., socio-economic vulnerability) and results to lower sensitivity (biophysical vulnerability). Thus, sensitivity and adaptive capacity are also linked and add up to total vulnerability (Bates et al., 2008).

Several studies have predicted climate change to have huge impacts on rural farmers in developing countries like Nigeria, as small-scale farmers are particularly vulnerable to climatic stresses and shocks. Agroforestry, or the use of trees in the cropping system to improve farm productivity, has been put forth as a potential strategy to improve farmers' ability to adapt to future climate changes. This study observed that the most effective way 
to cope with future climate variation and shocks will be to improve general livelihoods through increasing farm productivity and enhancing non-farm incomes and the study further noted that agroforestry practices have the potential to help farmers adapt to climate change through improving general household wellbeing in rural Nigeria and the need to stress the importance of location-specific evaluations of effective development strategies and the need for enhanced community participation in development practices.

\subsection{Climate change vulnerability to fishermen}

As global average temperature increases, rainfall patterns changes, extreme weather events become severe, sea level rises. Thus, this leads to environmental changes and this will directly affect fishery production and with significant impact on food security along many pathways. Fish reproduction, growth and migration patterns are all affected by temperature, rainfall and hydrology (Ficke et al., 2007). Therefore, changes in these parameters will shift patterns of species abundance and availability. As recently occurs in some part of Nigeria, changes in precipitation has affects seasonal flooding patterns and drives inland fish production in some areas and drier dry seasons may threaten stocks of both wild and cultured fish.

However, extreme weather events could further harm fish production in Nigeria by causing loss of aquaculture stock and destroying fishing and aquaculture infrastructure. Changes in fishery production are likely to have the greatest impact on people who depend on fishing as their primary livelihood activity, for example, the rural communities of riverine areas and coastal communities. As these people are often poorer and more marginal than those who own land and have other primary sources of income, the effects of climate change on fisheries will harm those least equipped to cope (Johnston et al., 2009). The International Panel on Climate Change (IPCC) has examined the implications of projected climate change for fishery production. Overall, it concludes that the sector is vulnerable to and has the potential to be strongly impacted by climate change (Bates et al., 2008).

\subsection{Climate change conflict between farmers and herdsmen}

The nexus between climate change and conflict in Nigeria is enormous, and findings shows that the immediate cause of Fulani-herdsmen and farmer's conflict in northern Nigeria is natural resource scarcity that the remote cause is climate change which has through drought and desertification led to the worsening incidence of natural resource scarcity and worsen conflict between the two especially as farmers moves from the arid zone savannah of northern Nigeria to the Guinea savannah of central state (Figure 2). However, as climate change is a contemporary issues and a gradual process in temperature, the government of Nigeria should to put more machinery on ground particularly in the north because over $70 \%$ of the nation's food crop comes from the zone by encouraging climate change mitigation and adaptation measures. Currently, heat waves and less rain, as well as drought and desertification as presently experienced in the north and have implications for climate conflict as recently occurring in Benue, Nasarawa and Plateau states of Nigeria. 
Figure 2 Model of climate conflict

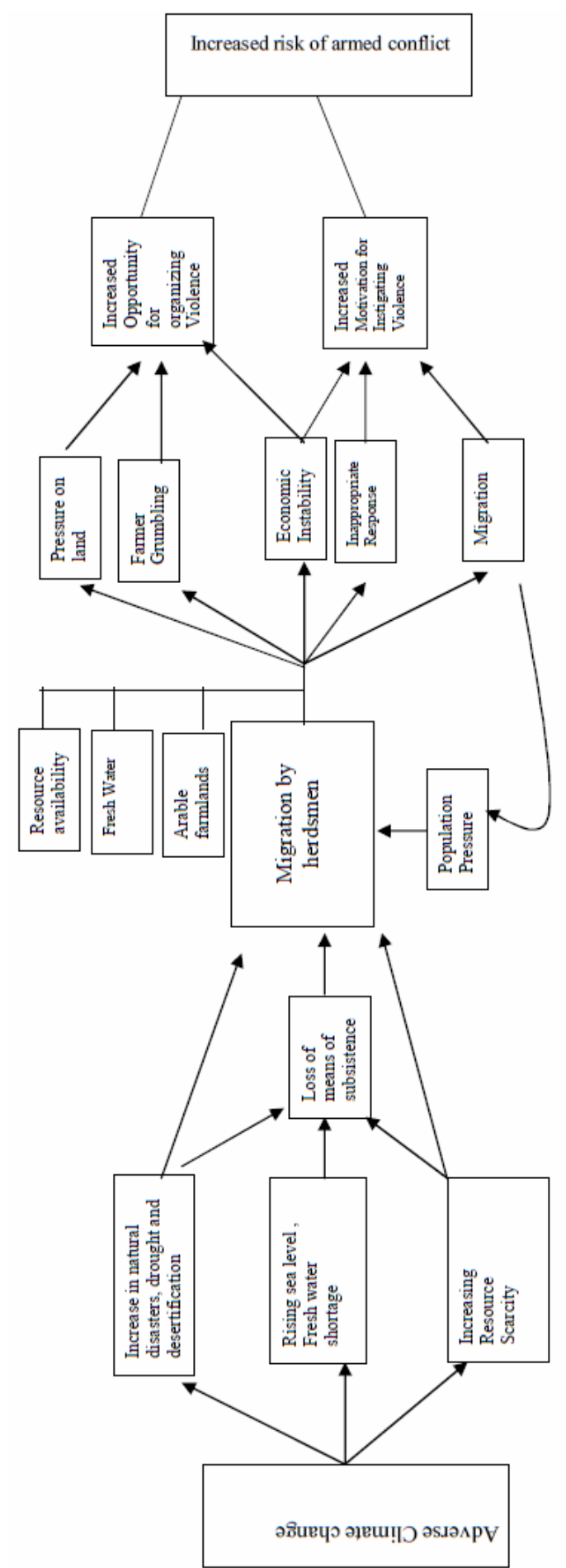

Source: Adapted from Odoh (2012) 
Most communal clashes in the country today are actually struggle over either the control of land or mineral resources or both. In the northern and middle parts of the country, the cereal-productive Sudan Savannah ecology is transiting to pure Sahel and the influence of the Sahara is increasing southwards. In the same vein, the root and tuber productive ecology of the Guinea Savannah is giving way to Sudan Savannah grassland. The predominant Fulani herdsman of the lower Sahel and Sudan Savannah ecologies is now moving south to the north central states within the Guinea Savannah and Forest belt of the South to find greener pasture for his herds.

Today, in Nigeria, environmental refugees is on the increase, and migrating people as a result of soil erosion, desertification, water shortages or the rise in sea level, now face such desperate living conditions that they can no longer continue in their original homes. Moreover, millions of people are fleeing temporarily from weather-related catastrophes such as droughts, floods and devastating storms. At the rate of which things are, the environmental refugees will look for other places to live, in the middle belt region of Nigeria, this situation creates a very serious potential for conflict. In some regions and conflict situations, there could even be violent clashes over habitable land and natural resources such as freshwater.

\subsection{Farmers and fishermen adaptation to climate change}

Adaptation to climate change refers to adjustment in natural or human systems in response to actual or expected climatic stimuli or their effects, which moderates harm of exploits beneficial opportunities (IPCC, 2001). Common adaptation methods in agriculture include use of new crop varieties and livestock species that are better suited to drier conditions, irrigation, crop diversification, adoption of mixed crop and livestock farming systems, and changing planting dates (Bradshaw et al., 2004; Kurukulasuriya and Mendelson, 2008; Nhemanchena and Hassan, 2007). The locals here however, are burdened under the weight of declining climatic conditions, poor agricultural yield and its effect on their standard of living due to inadequate understanding and conceptualisation of the challenges at hand and the measures that can be employed in adapting to them. Building fisher communities' capacity to adapt to these more immediate changes goes hand-in-hand with improving their capacity to adapt to climate change. A far-reaching strategy to improve adaptive capacity and strengthen resilience promises to reduce poverty and enhance food production now and in the years to come.

\section{Conclusions}

Climate change has been revealed to have several aspects to it besides physical. There is a social, cultural and economic aspect to climate change. Only the affected people especially the fishermen, farmers and herdsmen can explain how the changes in climate are made manifest. The observations made here can serve as a pointer into other areas that has been overlooked by scientific researchers. So also, the perception of people to climate change influences their response to it. This could also serve as a platform for policies geared towards mitigation to be to be designed at different levels of government. There is also need for proper enlightenment of the vulnerable people in climate change matters and adaptation measures and improving the development of country farmers' 
income as one of the most effective ways to reducing their vulnerability to climate change. It has been established that, fishermen and farmers are among the most vulnerable to climate variability, therefore, agroforestry, or the intentional use of trees in the cropping system, is a potential strategy to help farmers reduce their vulnerability to climate-related hazards and sustainable fish farming with adaptive strategies will also minimises the vulnerability of fishermen to climate disasters. However, Adger et al. (2005) also highlight the need to facilitate adaptation strategies among individuals and not solely rely on individual autonomy to make the most effective decision in vulnerability measures and adaptive strategies.

\section{References}

Adesina, F.A. and Adejuwon, J.O. (1994) 'Climate change and potential impact on biomass energy production in Nigeria: a preliminary assessment', Paper presented at the International Workshop on the Impact of Global Climate Change on Energy Development, Lagos Nigeria, 28-30 March.

Adger, W., Arnell, N. and Tompkins, E. (2005) 'Successful adaptation to climate change across scales', Global Environmental Change, Vol. 15, No. 2, pp.77-86.

Al-Amin, A.Q. and Filho, W.L. (2011) 'An overview of prospects and challenges in the field of climate change in Malaysia', Int. J. of Global Warming, Vol. 3, No. 3, pp.390-402.

Alessa, L., Kliskey, A., Williams, P. and Barton, M. (2008) 'Perception of change in freshwater in remote resource-dependent Arctic communities', Global Environmental Change, Vol. 18, No. 1, pp.153-164.

Awosika, L.F., French, G.T., Nicholls, R.T. and Ibe, C.E. (1992) 'The impacts of sea level rise on the coastline of Nigeria', in O'Callahan, J. (Ed.): Global Climate Change and the Rising Challenge of the Sea; Proceedings of the IPCC Workshop, Margarita Island, Venezuela, 9-13 March, National Oceanic and Atmospheric Administration, Silver Spring, MD, USA, 690pp.

Bates, B.C., Kundzewicz, Z.W., Wu, S. and Palutikof, J.P. (Eds.) (2008) Climate Change and Water, Technical Paper of the Intergovernmental Panel on Climate Change, IPCC Secretariat, Geneva, 210pp.

Berkes, F. and Jolly, D. (2001) 'Adapting to climate change: social-ecological resilience in a Canadian Western Arctic Community', Conversation Ecology, Vol. 5, No. 2, p.18.

Berkes, F., Colding, J. and Folke, C. (2000) 'Rediscovery of traditional ecological knowledge as adaptive management', Ecological Applications, Vol. 10, No. 5, pp.1251-1262.

Bradshaw, B., Dolan, H. and Smith, B. (2004) 'Farm-level adaptation to climatic variability and change: crop diversification in the Canadian prairies', Climatic Change, Vol. 67, No. 1, pp.119-141.

Chaliha, S., Sengupta, A., Sharma, N. and Ravindranath, H. (2012) 'Climate variability and farmer's vulnerability in a flood-prone district of Assam', International Journal of Climate Change Strategies and Management, Vol. 4, No. 2, pp.179-200.

Cline, W.R. (2007) Global Warming and Agriculture: Impact Estimates by Country, Centre for Global Development, Peterson Institute for International Economics, Washington, DC.

Couzin, J. (2007) 'Opening doors to indigenous knowledge', Science, Vol. 315, No. 5818, pp.1518-1519.

Danielsen, F., Burgess, N.D. and Balmford, A. (2005) 'Monitoring matters: examining the potential of locally-based approaches', Biodiversity and Conservation, Vol. 14, No. 11, pp.2507-2542.

Ficke, A.D., Myrick, C.A. and Hansen, L.J. (2007) 'Potential impacts of global climate change on freshwater fisheries', Reviews in Fish Biology and Fisheries, Vol. 17, No. 4, pp.581-613. 
Gallopin, G.C. (1997) 'Indicators and their use: information for decision-making', in Moldan, B. and Billharz, S. (Eds.): Sustainability Indicators, pp.13-28, Wiley, New York, NY.

Grundman, R. (2007) 'Climate change and knowledge politics', Environmental Politics, Vol. 16, No. 3, pp.414-432.

Intergovernmental Panel on Climate Change (IPCC) (2001) Third Assessment Report: Climate Change 2001, Intergovernmental Panel on Climate Change, Cambridge University Press, Cambridge.

Intergovernmental Panel on Climate Change (IPCC) (2007a) 4th Assessment Report: Synthesis Report-Summary for Policy Makers [online] http://www.ipcc.ch/pdf/assessment-report/ar4/syr/ar4_syr_spm.pdf (accessed 16 June 2012).

Intergovernmental Panel on Climate Change (IPCC) (2007b) 4th Assessment Report: Mitigation of Climate Change-Summary for Policy Makers, Working Group III [online] http://www.ipcc.ch/pdf/assessment-report/ar4/wg3/ar4-wg3-spm.pdf (accessed 16 June 2012).

International Food Policy Research Institute (IFPRI) (2008) Measuring Ethiopian Farmers' Vulnerability to Climate Change Across Regional States, IFPRI Division Discussion Paper 00806), October, Environment and Production Technology Division.

Johnston, R., Hoanh, C.T., Lacombe, G., Noble, A., Smakhtin, V., Suhardiman, D., Kam, S.P. and Choo, P.S. (2009) 'Scoping study on natural resources and climate change in Southeast Asia with a focus on agriculture', Report prepared for the Swedish International Development Cooperation Agency, International Water Management Institute, Colombo, and World Fish Center, Penang, Malaysia.

Krupnik, I. and Jolly, D. (Eds.) (2002) The Earth is Faster Now - Indigenous Observations of Arctic Environmental Change, Arctic Research Consortium of the United States, Fairbanks, AL.

Kurukulasuriya, P. and Mendelsohn, R. (2008) 'A Ricardian analysis of the impact of climate change on African cropland', African Journal of Agricultural and Resource Economics, Vol. 2, No. 1, pp.1-23.

Laidler, G.J. (2006) 'Inuit and scientific perspectives on the relationship between sea ice and climate change', The Ideal Complement? Climatic Change, Vol. 78, Nos. 2-4, pp.407-444.

Lawrence, A. (2009) 'The first cuckoo in winter: phenology, recording, credibility and meaning in Britain', Global Environmental Change, Vol. 19, No. 2, pp.173-179.

Leal Filho, W. (2009) 'Communicating climate change: challenges ahead and action needed', International Journal of Climate Change Strategies and Management, Vol. 1, No. 1, pp.6-18, Emerald Group Publishing Limited.

Macchi, M., Oveido, G., Gotheil, S., Cross, K., Boedhihartono, A., Wolfanegel, C. and Howell, M. (2008) Indigenous and Traditional People and Climate Change, IUCN Issues Paper [online] http://cmsdata.iucn.org/downloads (accessed 28 August 2012).

Marta, B.S. and Alexandre, S.G. (2012) 'Reflecting on the challenges and barriers of performing climate change vulnerability assessments in Scotland', Int. J. of Global Warming, Vol. 4, Nos. 3/4, pp.346-364.

Medugu, N.I., Majid, M.R. and Choji, I.D. (2008) 'A comprehensive approach to drought and desertification in Nigeria: a brief evaluation of government policies', Management of Environmental Quality: An International Journal, Vol. 19, No. 6, pp.690-704, Emerald Group Publishing Limited.

Medugu, N.I., Majid, M.R. and Johar, F. (2009) 'The consequences of drought and desertification in Nigeria', The IUP Journal of Environmental Sciences, Vol. 3, No. 3, pp.66-84.

Medugu, N.I., Majid, M.R., Johar, F. and Choji, I.D. (2010) 'The role of afforestation programme in combating desertification in Nigeria', International Journal of Climate Change Strategies and Management, Vol. 2, No. 1, pp.35-47.

Nasiru, I.M. (2009) 'Combating climate change in Nigeria', Leadership Newspapers Nigeria, Published on 30 June, No. 961, p.15. 
Nelson, A. (2010) 'Biofuels adoption in Nigeria: a preliminary review of feedstock and fuel production potentials', Management of Environmental Quality: An International Journal, Vol. 21, No. 6, pp.785-795.

Nhemanchena, C. and Hassan, R. (2007) Micro-level analysis of farmers' adaptation to climate change in Southern Africa, IFPRI Discussion Paper No. 00714, International Food Policy Research Institute, Washington, DC.

Odoh, S.I. (2012) 'Climate change and conflict in Nigeria: a theoretical and empirical examination of the worsening incidence of conflict between Fulani Herdsmen and farmers in northern Nigeria', Arabian Journal of Business and Management Review, (oman chapter), Vol. 2, No. 1, p.110.

Oluyole, F. (2012) 'Coping with the menace of climate change in Nigeria', The Nigerian Pilot.

Salick, J. and Byg, A. (Eds.) (2007) 'Indigenous People and climate change', Tyndall Centre, Oxford, UK [online] http://www.tyndall.ac.uk/publications/Indigenouspeoples.pdf (accessed 28 August 2012).

Salick, J., Amend, A., Gunn, B., Law, W., Schmidt, H. and Byg, A. (2006) 'Tibetan medicine plurality', Economic Botany, Vol. 60, No. 3, pp.227-253.

Stern, N. (Ed.) (2006) 'The economics of climate change', The Stern Review, p.692, Cambridge University Press, Cambridge, UK.

Stringer, L.C., Dyer, J.C., Reed, M.S., Dougill, A.J., Twyman, C. and Mkwambisi, D. (2009) 'Adaptations to climate change, drought and desertification: local insights to enhance policy in southern Africa', Environ. Sci. Policy, Vol. 12, No. 7, pp.748-765.

Turner, N. (2009) 'It's so different today, climate change and indigenous life ways in British Columbia, Canada', Global Environmental Change, Vol. 19, No. 2, pp.180-190.

Van Aalst, M.K., Cannon, T. and Burton, I. (2008) 'Community level adaptation to climate change: the potential role of participatory community risk assessment', Global Environmental Change, Vol. 18, No. 1, pp.165-179.

Vedwan, N. and Rhoades, R.E. (2001) 'Climate change in the western Himalayas of India: a study of local perception and response', Climate Research, Vol. 19, No. 2, pp.109-117.

Zaku, A.H. (2009) 'Contribution of agriculture to GDP low', Leadership Newspaper, Nigeria, [online] http://www.leadershipnigeria.com/7635 (accessed 23 October 2011). 